\title{
Past, present, and future roles of small cladoceran Bosmina longirostris (O. F. Müller, 1785) in aquatic ecosystems
}

\author{
Małgorzata Adamczuk
}

Received: 7 May 2015/Revised: 28 August 2015/Accepted: 14 September 2015/Published online: 23 October 2015

(C) The Author(s) 2015. This article is published with open access at Springerlink.com

\begin{abstract}
Bosmina longirostris is a small-bodied, filter-feeding cladoceran. The species is widely distributed throughout the world in temperate and tropical climates, where it persists in all kinds of freshwater bodies regardless of their trophy, acidification, or salinity. Its wide distribution causes $B$. longirostris to be one of the most taxonomically recognizable Cladocera species all over the world, despite the fact that the species is a well-known example of a taxon with confused taxonomy. Although B. longirostris often displays high abundances in the world's freshwaters and sporadic studies on its feeding suggest that the species can have an important role in energy transfer throughout the food web, $B$. longirostris is still perceived by scientists as having a minor role in the classical food web structure. This perception of $B$. longirostris as a food web component could be altered in the near future due to global climatic changes, including increases in temperature which may cause cyanobacterial blooms that may be more harmful to Daphnia than B. longirostris. The response of $B$. longirostris to environmental, competitive, and predatory conditions has been repeatedly studied to search for application of that
\end{abstract}

Handling editor: Karl E. Havens

M. Adamczuk ( $\square)$

Department of Hydrobiology, University of Life Sciences,

B. Dobrzańskiego 37, 20-262 Lublin, Poland

e-mail: malgorzata.adamczuk@up.lublin.pl species as indicator in ecological, neolimnological, and paleolimnological research. Regardless of its common use as test species in ecological and limnological studies, B. longirostris still lacks appropriate study by researchers because of its problematic systematics. Research directed at this species seems to be hampered by the absence of an accurate taxonomical revision of $B$. longirostris or group of cryptic species called $B$. longirostris.

Keywords Bosminidae $\cdot$ Food web - Indicator · Cryptic species

\section{Introduction}

The Cladocera (commonly called water fleas) constitute an ancient clade of branchiopod crustaceans comprising 16 or 18 family lineages (Olesen, 1998; Stenderup et al., 2006). Most of these are herbivorous filter-feeders. They are known to switch between parthenogenetic and sexual reproduction when environmental conditions for growth and reproduction deteriorate (Taylor et al., 1999). They are relatively tolerant to environmental conditions, which would confirm their opportunistic and potentially invasive nature. As a result, Cladocera are distributed circumglobally and mostly occur in temporary or permanent freshwater pools, although a few species have colonized marine or brackish habitats (Richter et al., 
2007). Cladocerans fulfill the pivotal role in aquatic food webs, for, through their grazing activities on picoplankton, nannoplankton, and microplankton populations, they function as intermediaries between lower trophic levels and fish. Currently, there are more than 600 known taxa of Cladocera (Korovchinsky, 1996). Among cladocerans, Daphnia genus is considered to be crucial for their ability to determine water quality due to its key role in biomass transfer between phytoplankton and planktivorous fish.

A small-bodied, filter-feeding cladoceran called Bosmina longirostris is one of the most recognizable species of Cladocera due to the round shape of its carapace, the easily distinguishable form of its postabdomen, and the distinctive shapes of its appendages, including chitinous anterior and posterior protuberances called antennules and mucrones, respectively. B. longirostris is widely distributed throughout the world in temperate and tropical climates including Holarctic, Nearctic, Palearctic, Neotropical, and Ethiopian regions. Although $B$. longirostris is a commonly distributed typical representative of branchiopod crustaceans, it is regarded to have a minor role in energy transfer through aquatic food webs due to its small body size resulting in their narrow food niche and minor role in the diets of fish. For a long period of time, B. longirostris constituted an interesting research subject for its defense mechanisms against predatory invertebrates that appear in the shape and longevity of its appendages. An interest in the ecology of $B$. longirostris has increased, since some studies have reported probable changes in food web components caused by current climate changes. Those changes may include the diminishment of Daphnia as a key herbivore and the increase of smallbodied cladocerans. Thereby, a number of studies have undertaken the challenge of testing how changes in the environment influence small herbivores represented mostly by $B$. longirostris. This has been done to predict future changes in aquatic ecosystems. These studies show that $B$. longirostris is more tolerant than other cladocerans to a large number of the stresses which may happen under natural conditions. Undoubtedly, this has increased scientific interest in this species.

In this paper, I discuss taxonomic problems of $B$. longirostris, summarize the growing body of literature on the applicable role of B. longirostris in paleolimnological, neolimnological, and ecological studies, and highlight its potential role as a food web component on the grounds of its tolerance to unfavorable environmental conditions. I hope the review will encourage others and provide a firm foundation for future research on B. longirostris.

\section{Confusing morphology}

Despite some clear features identifying $B$. longirostris all over the world and its set phylogenetic status in Bosminidae family, the systematics of this species have notoriously caused confusion because $B$. longirostris shows clearly visible variance in the shape of its carapace, as well as the length and curvature of its appendages. Indeed, this confusion has existed for more than 200 years. B. longirostris was described for the first time by Otto Friedrich Müller in 1785. Afterward, other morphs of $B$. longirostris were described as distinct species; namely $B$. curvirostris Fisher, 1854, B. cornuta G. O. Sars, 1862, B. brevicornis Hellich, 1877, B. similis G. O. Sars 1870, and B. pellucida Stingelin, 1895. Finally, these were recognized as morphotypes of a single species, $B$. longirostris, the morphotype of which was described by O. F. Müller and called typica (Fig. 1). Nonetheless, biologists are still not sure of the systematic affiliation of those morphotypes. Besides B. longirostris forma typica, morphotypes of cornuta, simillis, and pellucida are the most often encountered in the world's freshwaters. They show distinct differences in the length and shape of their appendages: forma typica has quite a short and straight antennule and middle-sized mucrone; forma similis has a long, straight antennule and long crenate mucrone; forma pellucida has a slightly curved antennule and middlesized mucrone; and forma cornuta has a hooked antennule and short mucrone (Margaritora, 1983; Lieder, 1996). Important diagnostic traits of $B$. longirostris include the head pores that are located on each side of the head in the region of the mandibular articulation (lateral head pores), on the median line above the compound eye (median head pores) (Goulden \& Frey, 1963), and above the rostrum, between the two frontal setae (frontal head pores) (Kořinek, 1971). Studies on the distribution and shape of head pores show differences between the populations of B. longirostris from North America and Europe as well as differences among European 
Fig. 1 Different morphotypes of $B$. longirostris: a typica, b curvirostris, c cornuta, d brevicornis, e similis, f pellucida (a)
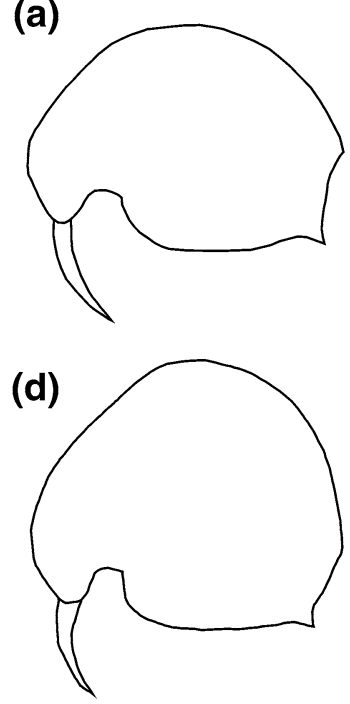

(b)

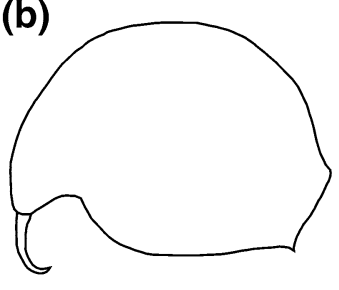

(e)

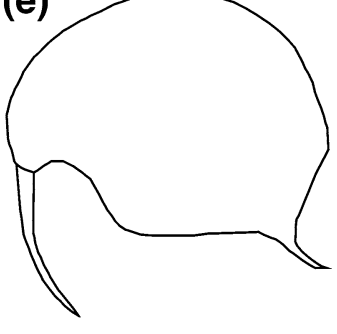

(c)
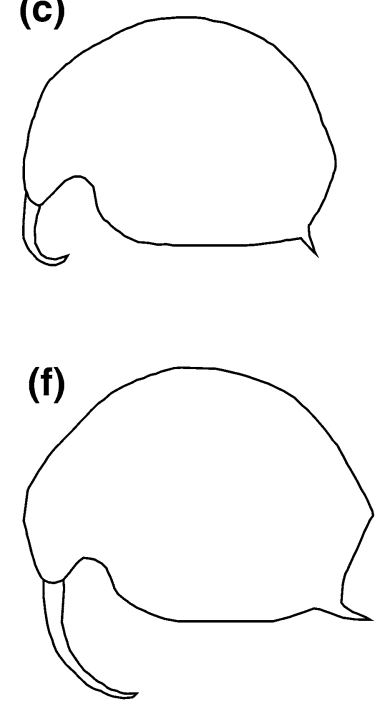

populations of the species. De Melo \& Hebert (1994) found that the lateral head pores of North American $B$. longirostris are circular, and their lateral projection under the microscope produces an elongated shape as an apparent image. Goulden \& Frey (1963), as well as Korrinek et al. (1997), established that the lateral head pores of European populations of B. longirostris are elongated, with a ventral margin which is nearly straight and a vaulted dorsal margin, and their lateral projection under the microscope produces an undistorted image. Hudec (1989) observed that differences in lateral head pores are morphotype specific, thus suggesting a species-specific derivation of the morphotypes in Slovakian populations of B. longirostris, whereas Kappes \& Sinsch (2002) supported the hypothesis that differences in the position of the lateral head pores are not morphotype specific in populations of B. longirostris from German lakes.

\section{Why so many morphological differences?}

Despite the unspecified phylogenetic status of the $B$. longirostris morphotypes, it has been observed that antennules and mucrones fulfill an important role in anti-predator defense behavior, and now it is widely accepted that morphotypes with elongated appendages are favored under conditions of high invertebrate predation. The role of appendages in anti-predator defense is such that individuals attacked by

invertebrate predators fold their single pair of swimming antennae into a groove behind the antennule and fall passively through the water column. During this motionless, dead-man behavior, fixed antennules protect the antennae, whereas mucrones protect against rotation toward the ventral groove region, through which feeding particles are filtered (Kerfoot, 1975a). When grasped by a predatory invertebrate, an individual with longer appendages is far more difficult to maneuver by a predator, and thus it has a greater probability of escaping from an encounter with a predator (Kerfoot, 1977, 1978; Post et al., 1995; Chang \& Chanazato, 2003). The extreme morphological features of $B$. longirostris tend to diminish when individuals are taken from natural populations and reared in the absence of predator stimuli (Kerfoot \& McNaught, 2010). Some studies have suggested that B. longirostris displays cyclomorphosis, i.e., seasonal polymorphism triggered by specific environmental variables (Hutchinson, 1967) which is an often observed phenomenon in cladocerans. The following patterns of life-history traits have been classified as cyclomorphosis in B. longirostris: (1) seasonal body size changes during spring and winter of large-sized, and during summer of small-sized individuals (Razak \& Saisho, 1970); (2) egg size with small eggs in spring and summer, and bigger eggs in autumn (Razak \& Saisho, 1970); (3) mucrone length with short mucrones during spring and summer and long mucrones during autumn (Kerfoot, 1975b); and (4) 
antennule length with short antennules in spring and early summer, and long antennules in late summer and autumn (Kerfoot, 1975b). Kappes \& Sinsch (2002) questioned the cyclomorphic changes in the length and shape of appendages, since they observed that cyclomorphosis in B. longirostris did not consist of a gradual change from one morphotype to another, but of a change in body shape within a morphotype. The phenomenon of the coexistence of different morphotypes within a population under laboratory conditions (Sakamoto et al., 2007) also weighs against the hypothesis of the seasonal occurrence of different morphotypes as the result of cyclomorphosis. To date, there have been no studies on the life history trade-offs of short- and long-appendaged B. longirostris, but it can be assumed that morphotypes of $B$. longirostris differ in life-history trade-offs, since reports on the costs of the phenotypic plasticity of other species of Cladocera have suggested that appendaged individuals have a lower intrinsic rate of population growth (Zaret, 1969; O’Brien \& Vinyard, 1978; Hebert \& Loaring, 1980), a lower rate of filtration (O'Brien \& Vinyard, 1978), and produce fewer eggs with more yolk (Kerfoot, 1977) in comparison to non-appendaged individuals.

\section{How does Bosmina longirostris grow?}

Kappes \& Sinsch (2002), who studied phenotypic differentiation among typica, pellucida, and cornuta morphotypes, found no gradual changes from one morph to another during ontogenic development. Concurrently, they concluded that only adult individuals showed morphological traits characteristic to distinct morphs, whereas juveniles mainly resembled the morph pellucida, and only a few cornuta, which is in slight contradiction to their former statement. Sakamoto \& Hanazato (2009), when studying the relations between the invertebrate predation and morphologic plasticity of $B$. longirostris, found that, although adults were pellucida or cornuta morphotypes, all juvenile individuals presented pellucida morphotypes. Sakamoto et al. (2007) cultured separately three monoclonal populations of $B$. longirostris descending from three distinct clones under conditions of optimal food and without predatory pressure. They found that in each of the monoclonal populations, cornuta: typica and pellucida morphotypes occurred, and the ratio of cornuta: typica/pellucida was 65.8:34.2 in the first population, and respectively, 43:57 in the second population, 92.6:7.4 in the third population. Thus, contrary to Kappes \& Sinsch (2002) who concluded that antennule shapes are invariable phenotypes, Sakamoto et al.'s studies showed that morphotypes of typica, pellucida and cornuta are not hereditarily rigid phenotypes within a species. Those findings could suggest strong spontaneous epigenetic regulation of phenotypes in B. longirostris. Sakamoto \& Hanazato (2009) compared the length of antennules and mucrones and body size between different treatments (laboratory versus field and predator versus no predator conditions) concluding that the smallest (thus, probably the youngest) individuals had significantly longer antennules and mucrones than larger ergo older individuals. This could be explained by their atypical growth consisting of a progressive reduction in the lengths of antennules and mucrones during the ontogenic development of $B$. longirostris. This could also suggest that anti-predator defense mechanisms mainly appear in juvenile individuals and disappear steadily during maturation. If atypical growth of antennules and mucrones is possible, this can suggest steady shifts from the pellucida morph to cornuta or typica morphotypes, despite the fact that some authors have rejected such a possibility. Thus, the hypothesis that different morphotypes are not genetically distinct forms, but are only developmental stages in the ontogenic development of B. longirostris is highly possible.

\section{Bosmina longirostris as a food web component}

Despite the common occurrence and often high abundances of $B$. longirostris in the world's freshwaters, the species is perceived as having a minor role in classical food web structure. The assignment to $B$. longirostris of such low importance in aquatic food webs results from its relatively small body size. It is assumed in mechanistic models that the body sizes of herbivorous zooplankton determine their grazing selectivity patterns and the size range of the grazed algae. Thus, according to that assumption small herbivores (e.g., B. longirostris) mainly feed upon small phytoplankton, and large herbivores (e.g., Daphnia species) feed on a wider size range of phytoplankton (Hansson et al., 1998). Contrary to that 
assumption, experimental studies have displayed shifts to small algae in the presence of small grazers and shifts to larger algae as grazer size increased (Carpenter \& Kitchell, 1984; Berquist et al., 1985). Despite the fact that the role of $B$. longirostris in the classical food web is not clear, its role in the microbial food web is truly unquestionable. The abilities of Daphnia and B. longirostris to depress the densities of ciliata and heterotrophic nanoflagellates are similar (Burns \& Schallenberg, 1996; Jürgens et al., 1996), but $B$. longirostris is more effective than Daphnia in feeding bacteria (De Mott, 1982). Thus, since $B$. longirostris affects each level of the microbial loop, the species can have a key role in transferring energy, carbon cycling, and nutrient remineralization throughout the microbial and classical food web. The role of $B$. longirostris in the food web is also enhanced by its ubiquitous behavior in lakes. Just as the Daphnia avoidance of littoral habitats is well known (Lauridsen \& Lodge, 1996; Bergstrőm et al., 2000), B. longirostris shows quite even horizontal and vertical distributions (Adamczuk, 2012a) suggesting its similar trophic role in both littoral and pelagic food webs.

\section{Bosmina longirostris as an indicator of the past}

Bosmina longirostris and other Bosminidae constitute an important group of indicators in paleolimnological studies. The successful use of bosminids in that field of science stems from their cosmopolitanism, excellent preservation of body parts in sediments (Jeppesen et al., 2001), and the ease of discerning Bosmina species from head shields (Szeroczyńska \& SarmajaKorjonen, 2007). The shape of B. longirostris shields provides us with important information about past predatory pressure (Korosi et al., 2013). Paleoecological studies conducted by Kerfoot (1981) revealed progressive shifts from late-glacial long-appendaged morphotypes to the recent dominance of short-appendaged morphotypes, suggesting long-term changes in dominant predatory types. These results were later supported by Sanford (1993) who showed the extended dominance of forma cornuta as a response to the diminishment of invertebrate predation in favor of predation by planktivorous fish. Currently, the proportion of cornuta to morphotypes with long attennules is commonly used in paleolimnology as an indicator of fish predation (Sanford, 1993; Salo et al., 1994). It remains to be suggested that the dominance of $B$. longirostris is also useful for quantitative reconstruction of the eutrophication process, as the domination of $B$. longirostris along with elevated nutrient status has been observed in many paleolimnological studies of European lakes (Nevalainen \& Luoto, 2012; Jensen et al., 2013; Nevalainen et al., 2013). The replacement of $E$. coregoni and E. longispina by $B$. longirostris is regarded as a classical case of eutrophication-induced species succession in the past millennia (Goulden, 1964; Crisman \& Whitehead, 1978). Nonetheless, studies in Arctic lakes did not support the role of $B$. longirostris as an indicator of eutrophication processes and have proposed this species as an indicator of deep and clear water, since Frolova et al. (2014) found that $B$. longirostris was associated with deep, clear Siberian lakes, and Davidson et al. (2011) linked the occurrence of $B$. longirostris to deeper sites and the presence of fish in lakes in Greenland.

\section{Bosmina longirostris in an unpredictable world}

The world's freshwaters are considered to be subject to intense climate changes with prospective climateinduced alterations in the structure and function of aquatic ecosystems, including further eutrophication of already eutrophic lakes (Moss et al., 2011), an increase in salinity in coastal lakes (Zehrer et al., 2015), higher proportions of cyanobacteria in summer (Wagner \& Adrian, 2009; Kosten et al., 2012), changes in physiological processes (Hawkins, 1995), and changes in response to predation regimes resulting in significant changes in community composition and energy transfer through food web structures (Emmerson et al., 2005; Jeppesen et al., 2010; Adamczuk et al., 2015a). Temperature elevation and ongoing cultural eutrophication could create favorable conditions for $B$. longirostris. Paleolimnological studies have shown that B. longirostris has invaded warming waters, including originally coldwater high Alpine lakes where $B$. longirostris had previously been absent or rare. However, once these waters started to warm up, B. longirostris invaded them and quickly became the dominant species of Cladocera (Nevalainen \& Luoto, 2012; Nevalainen et al., 2014). Correlations between increased temperatures and the abundance of $B$. longirostris have also been noted in long-term 
neolimnological research (Adamczuk et al., 2015b). The preferences of $B$. longirostris for eutrophic conditions were described above; thus, it is predicted that the species will be dominant in an increasing number of eutrophying lakes. B. longirostris also tolerates salinity (Aladin, 1991; Jeppesen et al., 1994; Deasley et al., 2012) and shows higher resistance to acidification than bigger cladocerans. Its dominance in saline and acid environments results from its ability to cope with changing chemical conditions, decreased competition for food, and decreased predation pressure from invertebrates. In their experiment with controlled $\mathrm{pH}$ reduction, Havens \& DeCosta (1985) found that compared with the control treatment, acidification resulted in a decreased abundance of planktonic invertebrates, except for $B$. longirostris, the abundance, biomass, and mean body size of which even increased during the acid treatment (Havens et al., 1993; Locke \& Sprules, 2000). As B. longirostris is able to grow and reproduce under rapidly changing $\mathrm{pH}$ levels and highly acidic conditions, it is, thus, often the single dominant species in acidified lakes (Yan \& Strus, 1980).

For many years, the dogma of Daphnia as a superior competitor over B. longirostris has been repeated (Goulden et al., 1982; Vanni, 1986). However, recent studies suggest that expected climate changes may favor $B$. longirostris at the cost of Daphnia. The conditions of elevated water temperature in conjunction with the occurrence of blooms of toxic blue-green alga enhance the exclusion of Daphnia and dominance of $B$. longirostris (Figueroa-Sanchez et al., 2014; Jiang et al., 2014). $B$. longirostris is resistant to strains of Microcysits aeruginosa and Anabaena flosaquae that have lethal toxic effects on other cladocerans (Fulton, 1988); thus, this species can potentially coexist with toxic bluegreen alga blooms (Jiang et al., 2013). Some studies report that $B$. longirostris is even able to consume them (Fulton, 1988). Changes in food web structure, primarily warmth-induced changes in fish communities, can be to the detriment of Daphnia and benefit $B$. longirostris. Fish communities in warm waters have fever strictly piscivorous fish but more of omnivores (Meerhoff et al., 2007; Texeira de Mello et al., 2009; Moss, 2010), including small, rapidly reproducing fish (Jeppesen et al., 2010) which can remove virtually all effective grazers, including Daphnia. Since Wells (1970) observed that the successful invasion of alewife, Alosa psudoharengus, into Lake Michigan was associated with depressed densities of largebodied cladoceran taxa and with increased densities of smaller taxa, mainly B. longirostris, we have noted evidence of Daphnia loss in favor of B. longirostris under conditions of high pressure of planktivorous fish (Nilsson \& Pejler, 1973; Chappaz et al., 1999; Lampert et al., 2014).

So, what can limit the successful spread of $B$. longirostris? Despite the high level of ability of $B$. longirostris to tolerate conditions that seem to be highly unfavorable for other cladocerans, B. longirostris turns out to be sensitive to metal contamination. The sensitivity of $B$. longirostris to metal contamination has been supported both under laboratory and field conditions suggesting that $B$. longirostris is more sensitive to metal contamination than Daphnia (Koivisto et al., 1992; Koivisto \& Ketola, 1995 Labaj et al., 2015). The differences in sensitivity result from size differences between the species, for large cladocerans accumulate lower amount of metals than smaller cladocerans (Rainbow \& Moore, 1986; Lasenby \& Van Duyn, 1992). Given that metal contamination of lakes is caused by anthropogenic activity, this factor can effectively limit the current and future density and dominance of this species. Another threat for B. longirostris is connected to the projected dominance of invertebrate predators in food webs. It has been experimentally showed that the activity of invertebrate predators increases under warmer conditions (Beisner et al., 1996). B. longirostris is highly vulnerable to carnivorous invertebrates (Von Ende \& Dempsey, 1981; Branstrator \& Lehman, 1991; Adamczuk, 2012b), and climate-induced changes in aquatic ecosystems can result in domination of small invertebrate predators (Daufresne et al., 2009; Rice et al., 2014) that are primarily damaging for small prey, including $B$. longirostris.

\section{Bosmina longirostris responses to environmental disturbances}

Performance of $B$. longirostris across all environments and high fitness levels over a range of environmental conditions suggest that $B$. longirostris has a generalist genotype. Moreover, conditions of rapid changes seem to even favor B. longirostris. Hart (2004) found that $B$. 
longirostris is quite numerous in periods of annual overturn in an environment. On the basis of that discovery, he classified B. longirostris as a 'disturbance-tolerant' species. That term seems to be the most adequate when taking into consideration the high adaptive ability of $B$. longirostris to changing environmental conditions. Studies on competition between B. longirostris and Daphnia in experimentally manipulated habitats have revealed the ability of $B$. longirostris to rapid adaptation to a changing environment that has resulted in its outcompeting Daphnia (Goulden et al., 1982; Kurmayer, 2001; Jiang et al., 2014) An advantage of B. longirostris over Daphnia under disturbed conditions can result from some differences between these two taxa. Primarily, $B$. longirostris is more efficient than Daphnia in carbon production, especially at low food conditions (Urabe, 1991). B. longirostris also has lower phosphorus content in comparison to Daphnia (Reissig et al., 2015). As a result, Daphnia, although larger, cannot outcompete B. longirostris under decreased food conditions (Goulden et al., 1982).

\section{Future challenges}

The common use of $B$. longirostris as indicator of environmental conditions in paleolimnology and neolimnology conflicts with its underestimated role as a food web component. Sporadic studies on the feeding of B. longirostris suggest that the species could have a more important role in energy transfer throughout the food web than is currently recognized. This role could increase due to global climate changes, including increases in temperature enhancing bluegreen alga blooms which are destructive for Daphnia and tolerable for $B$. longirostris. The role of $B$. longirostris in aquatic ecosystems is difficult to study without prior explanation of the morphotypic derivation and distribution of genetic variants of $B$. longirostris. Currently, there is a tendency to perceive $B$. longirostris as a cosmopolitan species. Nevertheless, the existence of cryptic species (i.e., distinct species that are classified as one due to morphological similarity) in the group of $B$. longirostris is also highly possible. Taylor et al. (2002) concluded his studies on phylogeny of Bosminidae with the suggestion that all subgenera within bosminids may contain cryptic species that may account for the seemingly widespread distribution of that family across environmental gradients. The possibility of this phenomenon can be supported by the subtle morphological differences observed in $B$. longirostris, including inter(Europe versus North America) (Goulden \& Frey, 1963; De Melo \& Hebert, 1994; Kořinek et al., 1997) and intracontinental (Slovakia versus Germany) (Hudec, 1989; Kappes \& Sinsch, 2002) differences in the shape and position of head pores described in this review, as well as contradictory premises of $B$. longirostris preferences for shallow and eutrophic European lakes versus the deep and clear lakes of Greenland. In this case, the cryptic diversity of $B$. longirostris may bias results of ecological studies if cryptic species possess different ecological characteristics. Phenotypic observations on morphotypes of $B$. longirostris provide strong evidence of their environmentally induced (Razak \& Saisho, 1970; Kerfoot, 1975b; Sakamoto \& Hanazato, 2009), spontaneously phenotypic (Sakamoto et al., 2007), genotypic, and rigidly hereditary (Kappes \& Sinsch, 2002) or maybe ontogenic (Sakamoto \& Hanazato, 2009) derivation. Simultaneous environmental, spontaneous, ontogenic, and genotypic bases of some traits in single species do not occur in biology; however, since each of these derivations of morphotypes is supported, it is hard to logically exclude any of them. Yet, if we predict the existence of cryptic species within the group of $B$. longirostris, all derivations of morphotypes are possible. Describing cryptic species could lead us to conclude that $B$. longirostris is not such a genotypic generalist as it is regarded currently. Understanding how genetic and phenotypic variability determines the plasticity of $B$. longirostris is crucial for predicting the species' rate of adaptation to environmental changes. As presented in this review, B. longirostris can persist under an amount of unfavorable conditions and shows a significant ability to adapt to rapid environmental changes. Although we understand the phenomenon of the dominance of $B$. longirostris under disturbed environmental conditions as a result of decreased competition for food and decreased predation pressure of invertebrates, we still do not know the genetic and physiological mechanisms of the resistance of $B$. longirostris to physical and chemical changes in the environment. Some responses of B. longirostris to varying conditions, including positive responses to eutrophication and temperature regimes, are transferred mainly as the outcome of paleolimnological 
studies. However, paleoreconstructions seem to have most of their limitations stemming from the selective preservation of taxa that causes problems in the recapture of complete food webs, and increasing anthropogenic influences that create difficulties in finding contemporary systems comparable with those reconstructed from ancient fossil remains. Thus, the short- and long-term responses of $B$. longirostris to elevated nutrients and increased water temperature should be reinvestigated in neolimnological studies. The tolerance levels of $B$. longirostris to salinity, acidification, toxins of blue-green algae, and resistance to rapid changes in environmental conditions need in-depth analyses on the basis of reliable and current field observations using modern techniques such as molecular biology. Nonetheless, only resolution of taxonomic problems will presume us to understand the ground of thorough-paced resistance of $B$. longirostris to unfavorable environmental conditions and its further use as a test species to study the role of genetic variation on stress tolerance and the mechanisms of adaptation of aquatic invertebrates on genetic, organismal, and population levels.

Acknowledgments I thank the two anonymous reviewers. Their constructive criticism helped greatly improve the previous draft of the paper.

Open Access This article is distributed under the terms of the Creative Commons Attribution 4.0 International License (http:// creativecommons.org/licenses/by/4.0/), which permits unrestricted use, distribution, and reproduction in any medium, provided you give appropriate credit to the original author(s) and the source, provide a link to the Creative Commons license, and indicate if changes were made.

\section{References}

Adamczuk, M., 2012a. Spatial distribution of juvenile and adult stages of limnetic Cladocera in relation to selected environmental factors. Journal of Limnology 71: 112-118.

Adamczuk, M., 2012b. The development and reproductive output of three species of Cladocera (Crustacea, Branchiopoda) with different size spectra as the result of vertebrate and invertebrate predation impact. Invertebrate Reproduction \& Development 56: 293-298.

Adamczuk, M., T. Mieczan, D. Nawrot \& J. Rechulicz, 2015a. Indirect effect of environmental factors on interactions between microbial and classical food webs in freshwater ecosystems. Annales de Limnologie.-International. Journal of Limnology 51: 49-58.
Adamczuk, M., T. Mieczan, M. Tarkowska-Kukuryk \& A. Demetraki-Paleolog, 2015b. Rotatoria-Cladocera-Copepoda relations in the long-term monitoring of water quality in lakes with trophic variation (E. Poland). Environmental Earth Sciences 73: 8189-8196.

Aladin, N. V., 1991. Salinity tolerance and morphology of the osmoregulation organs in Cladocera with special reference to Cladocera from the Aral Sea. Hydrobiologia 225: 291-299.

Beisner, B. E., E. Mccauley \& F. J. Wronas, 1996. Temperaturemediated dynamics of planktonic food chains: the effect of an invertebrate carnivore. Freshwater Biology 35: 219-232.

Bergstrőm, S. E., J. E. Svensson \& E. Westberg, 2000. Habitat distribution of zooplankton in relation to macrophytes in an eutrophic lake. Internationale Vereinigung fur Theoretische und Angewandte Limnologie Verhandlungen 27: 2861-2864.

Berquist, A. M., S. Carpenter \& J. C. Latino, 1985. Shifts in phytoplankton size structure and community composition during grazing by contrasting zooplankton assemblages. Limnology and Oceanography 30: 1037-1045.

Branstrator, D. K. \& J. T. Lehman, 1991. Invertebrate predation in Lake Michigan: regulation of Bosmina longirostris by Leptodora kindtii. Limnology and Oceanography 36: 483-495.

Burns, C. W. \& M. Schallenberg, 1996. Relative impacts of copepods, cladocerans and nutrients on the microbial food web of a mesotrophic lake. Journal of Plankton Research 18: $683-714$

Carpenter, S. R. \& J. F. Kitchell, 1984. Plankton community structure and limnetic primary production. American Naturalist 124: 159-172.

Chang, K. H. \& T. Chanazato, 2003. Vulnerability of cladoceran species tp predation by the copepod Mesocyclops leuckartii: laboratory observation on the behavioural interactions between predator and prey. Freshwater Biology 48: 476-484.

Chappaz, R., D. Doucende \& R. Barthelemy, 1999. Patterns of change in zooplankton community structures and the selective feeding of Bleak, Alburnus alburnus (L.) in the Serre Ponçon dam between 1980 and 1996. Hydrobiologia 391: $127-134$.

Crisman, T. L. \& D. R. Whitehead, 1978. Paleolimnological studies on small New England (USA) ponds. Part 1I. Cladoceran community responses to trophic oscillations. Polskie Archiwum Hydrobiologii 25: 75-86.

Daufresne, M., K. Lengfellner \& U. Sommer, 2009. Global warming benefits the small in aquatic ecosystems. Proceedings of the National Academy of Sciences 106: $12788-12793$.

Davidson, T. A., S. L. Amsinck, O. Bennike, K. S. Christoffersen, F. Landkildehus, T. L. Lauridsen \& E. Jeppesen, 2011. Inferring a single variable from an assemblage with multiple controls: getting into deep water with cladoceran lake-depth transfer functions. Hydrobiologia 676: $129-142$.

Deasley, K., J. B. Korosi, J. R. Thienpont, S. V. Kokelj, M. F. J. Pisaric \& J. P. Smol, 2012. Investigating the response of Cladocera to a major saltwater intrusion event in an Arctic 
lake from the outer Mackenzie Delta (NT, Canada). Journal of Paleolimnology 48: 287-296.

De Melo, R. \& P. D. N. Hebert, 1994. A taxonomic reevaluation of North American Bosminidae. Canadian Journal of Zoology 72: 1808-1825.

De Mott, W. R., 1982. Feeding selectivities and relative ingestion rates of Daphnia and Bosmina. Limnology and Oceanography 27: 518-527.

Emmerson, M., M. Bezemer, M. D. Hunter \& T. H. Jones, 2005. Global change alters the stability of food webs. Global Change Biology 11: 490-501.

Figueroa-Sanchez, M. A., N. Sarma \& S. S. S. Sarma, 2014. Zooplankton community structure in the presence of low levels of cyanotoxins: a case study in a high altitude tropical reservoir (Valle de Bravo, Mexico). Journal of Limnology 73: 157-166.

Frolova, L., L. Nazarova, L. Pestryakova \& U. Herzschuh, 2014. Subfossil Cladocera from surface sediment in thermokarst lakes in northeastern Siberia, Russia, in relation to limnological and climatic variables. Journal of Paleolimnology 52: 107-119.

Fulton, R. S. J., 1988. Resistance to blue-green algal toxins by Bosmina longirostris. Journal of Plankton Research 9: 837-855.

Goulden, C. E., 1964. The history of the cladoceran fauna Esthwaite Water (England) and its limnological significance. Archiv für Hydrobiologie 60: 1-52.

Goulden, C. \& D. G. Frey, 1963. The occurrence and significance of lateral head pores in the genus Bosmina (Cladocera). Internationale Revue der gesamten Hydrobiologie und Hydrographie 48: 513-522.

Goulden, C. E., L. L. Henry \& A. J. Tessier, 1982. Body size, energy reserves, and competitive ability in three species of Cladocera. Ecology 63: 1780-1789.

Hansson, L.-A., C. Brönmark, P. Nyström, L. Greenberg, P. Lundberg, P. A. Nilsson, A. Persson, L. B. Pettersson, P. Romare \& L. J. Tranvik, 1998. Consumption patterns, complexity and enrichment in aquatic food chains. Proceedings of the Royal Society of London Series B: Biological Sciences 265: 901-906.

Hart, R. C., 2004. Cladoceran periodicity patterns in relation to selected environmental factors in two cascading warm-water reservoirs over a decade. Hydrobiologia 526: 99-117.

Havens, K. \& J. DeCosta, 1985. The effect of acidification in enclosures on the biomass and population size structure of Bosmina longirostris. Hydrobiologia 122: 153-158.

Havens, K. E., N. D. Yan \& W. Keller, 1993. Lake acidification: effects on crustacean zooplankton populations. Environmental Science \& Technology 27: 1621-1624.

Hawkins, A. J. S., 1995. Effects of temperature change on ectotherm metabolism and evolution: metabolic and physiological interrelations underlying the superiority of multi-locus heterozygotes in heterogenous environments. Journal of Thermal Biology 20: 23-33.

Hebert, P. D. \& J. M. Loaring, 1980. Selective predation and the species composition of Arctic ponds. Canadian Journal of Zoology 58: 422-426.

Hudec, I., 1989. Distribution and biology of the family Bosminidae (Crustacea, Cladocera) in Slovakia. Biologia 44: 995-1008.
Hutchinson, G. E., 1967. A Treatise on Limnology, Vol. II. Introduction to Lake Biology and the Limnoplankton. Wiley, New York.

Jensen, T. C., I. Dimante-Deimantovica, A. K. Schartau \& B. Walseng, 2013. Cladocerans respond to differences in trophic state in deeper nutrient poor lakes from Southern Norway. Hydrobiologia 715: 101-112.

Jeppesen, E., P. Leavitt, L. De Meester \& J. P. Jensen, 2001. Functional ecology and paleolimnology: using cladocerans remains to reconstruct antropogenic impact. Trends in Ecology \& Evolution 16: 191-198.

Jeppesen, E., M. Søndergaard, E. Kanstrup, B. Petersen, R. B. Eriksen, M. Hammershøj, E. Mortensen, J. P. Jensen \& A. Have, 1994. Does the impact of nutrients on the biological structure and function of brackish and freshwater lakes differ? Hydrobiologia 275(276): 15-30.

Jeppesen, E., M. Meerhoff, K. Holmgreen, I. González-Bergonzoni, F. Teixeira-de Mello, S. A. J. Declerc, L. De Meester, M. Søndergaard, T. L. Lauridsen, R. Bjerring, J. M. Conde-Porcuna, N. Mazzeo, C. Iglesias, M. Reizenstein, H. J. Malmquist, Z. Liu, D. Balaya \& X. Lazzaro, 2010. Impacts of climate warming on lake fish community structure and potential effects on ecosystem function. Hydrobiologia 646: 73-90.

Jiang, X., Q. Li, H. Liang, S. Zhao, L. Zhang, Y. Zhao, L. Chen, W. Yang \& X. Xiang, 2013. Clonal variation in growth plasticity within a Bosmina longirostris population: the potential for resistance to toxic cyanobacteria. PLoS One 8: e73540.

Jiang, X., W. Yang, X. Xiang, Y. Niu, L. Chen \& J. Zhang, 2014. Cyanobacteria alter competitive outcomes between Daphnia and Bosmina in dependence on environmental conditions. Fundamental and Applied Limnology 184: 11-22.

Jürgens, K., S. A. Wickham, K. O. Rothhaupt \& B. Santer, 1996. Feeding rates of macro-and microzooplankton on heterotrophic nanoflagellates. Limnology and Oceanography 41: 1833-1839.

Kappes, H. \& U. Sinsch, 2002. Morphological variation in Bosmina longirostris (O. F. Müller, 1785) (Crustacea: Cladocera): consequence of cyclomorphosis or indication of cryptic species? Journal of Zoological Systematics and Evolutionary Research 40: 113-122.

Kerfoot, W. C., 1975a. The divergence of adjacent populations. Ecology 56: 1298-1313.

Kerfoot, W. C., 1975b. Seasonal changes of Bosmina (Crustacea, Cladocera) in Frains Lake, Michigan: laboratory observations of phenotypic changes induced by inorganic factors. Freshwater Biology 5: 227-243.

Kerfoot, W. C., 1977. Competition in cladoceran communities: the cost of evolving defenses against copepod predation. Ecology 58: 303-313.

Kerfoot, W. C., 1978. Combat between predatory copepods and their prey: Cyclops, Epischura, and Bosmina. Limnology and Oceanography 23: 1089-1102.

Kerfoot, W. C., 1981. Long-term replacement cycles in cladocerans communities: a history of predation. Ecology 62: 216-233.

Kerfoot, W. C. \& A. S. McNaught, 2010. Two-step dialogue between the cladoceran Bosmina and invertebrate 
predators: induction and natural selection. Limnology and Oceanography 55: 403-419.

Koivisto, S. \& M. Ketola, 1995. Effects of copper on life-history traits of Daphnia pulex and Bosmina longirostris. Aquatic Toxicology 32: 255-269.

Koivisto, S., M. Ketola \& M. Walls, 1992. Comparison of five cladoceran species in short- and long-term copper exposure. Hydrobiologia 248: 125-136.

Kořinek, V., 1971. Comparative study of head pores in the genus Bosmina Baird (Crustacea, Cladocera). Věstnik Československé Společnosti Zoologické 35: 275-296.

Kořinek, V., V. Sacherová \& L. Havel, 1997. Subgeneric differences in head shield and ephippia ultrastructure within the genus Bosmina Baird (Crustacea, Cladocera). Hydrobiologia 360: 13-23.

Korosi, J. B., J. Kurek \& J. P. Smol, 2013. A review on utilizing Bosmina size structure archived in lake sediments to infer historic shifts in predation regimes. Journal of Plankton Research 35: 444-460.

Korovchinsky, N. M., 1996. How many species of Cladocera are there? Hydrobiologia 321: 191-204.

Kosten, S., V. L. Huszar, E. Bécares, L. S. Costa, E. Donk, L. A. Hansson, E. Jeppesen, C. Kruk, G. Lacerot, N. Mazzeo, L. De Meester, B. Moss, M. Lürling, T. Nõges, S. Romo \& M. Scheffer, 2012. Warmer climates boost cyanobacterial dominance in shallow lakes. Global Change Biology 18: $118-126$.

Kurmayer, R., 2001. Competitive ability of Daphnia under dominance of non-toxic filamentous cyanobacteria. Hydrobiologia 442: 279-289.

Labaj, A. L., J. Kurek, A. Jeziorski \& J. P. Smol, 2015. Elevated metal concentration inhibit biological recovery of Cladocera in previously acidified Boral lakes. Freshwater Biology 60: 347-359.

Lampert, K. P., B. P. Regmi, I. Wathne \& P. Larsson, 2014. Clonal diversity and turnover in an overwintering Daphnia pulex population, and the effect of fish predation. Freshwater Biology 59: 1735-1743.

Lasenby, D. C. \& J. Van Duyn, 1992. Zinc and cadmium accumulation by the opossum shrimp Mysis relicta. Archives of Environmental Contamination and Toxicology 23: $179-183$.

Lauridsen, T. \& D. M. Lodge, 1996. Avoidance by Daphnia magna of fish and macrophytes: chemical cues and predator-mediated use of macrophyte habitat. Limnology and Oceanography 4: 794-798.

Lieder, U., 1996. Crustacea: Cladocera: Bosminidae. Gustav Fisher Verlag, Stuttgart.

Locke, A. \& W. G. Sprules, 2000. Effects of acidic pH and phytoplankton on survival and condition of Bosmina longirostris and Daphnia pulex. Hydrobiologia 437: 187-196.

Margaritora, F., 1983. Cladoceri (Crustacea: Cladocera). Guide per il riconoscimento delle specie animali della acque interne Italiane 22. Consiglio Nazionale Delle Ricerche, Rome.

Meerhoff, M., J. M. Clemente, F. Texeira de Mello, C. Iglesias, A. Pedersen \& E. Jeppesen, 2007. Can warm climate-related structure of littoral predator assemblies weaken the clear water state in shallow lakes? Global Change Biology 13: $1888-1897$

Moss, B., 2010. Climate change, nutrient pollution and the bargain of Dr Faustus. Freshwater Biology 55: 175-187.
Moss, B., S. Kosten, M. Meerhof, R. Battarbee, E. Jeppesen, N. Mazzeo, K. Havens, G. Lacerot, Z. Liu, L. De Meester, H. Paerl \& M. Scheffer, 2011. Allied attack: climate change and eutrophication. Inland Waters 1: 101-105.

Nevalainen, L. \& T. P. Luoto, 2012. Faunal (Chironomidae, Cladocera) responses to post-Little Ice Age climate warming in the high Austrian Alps. Journal of Paleolimnology 48: 711-724.

Nevalainen, L., T. P. Luoto, S. Kultti \& K. Sarmaja-Korjonen, 2013. Spatio-temporal distribution of sedimentary Cladocera (Crustacea: Branchiopoda) in relation to climate. Journal of Biogeography 40: 1548-1559.

Nevalainen, L., M. Ketola, J. B. Korosi, M. Manca, R. Kurmayer, K. A. Koinig, R. Psenner \& T. P. Luoto, 2014. Zooplankton (Cladocera) species turnover and long-term decline of Daphnia in two high mountain lakes in the Austrian Alps. Hydrobiologia 722: 75-91.

Nilsson, N. A. \& B. Pejler, 1973. On the relation between fish fauna and zooplankton composition in North Swedish Lakes. Report of the Institute of Freshwater Research Drottningholm 53: 51-77.

O’Brien, W. J. D. \& G. L. Vinyard, 1978. Polymorphism and predation: the effect of invertebrate predation on the contribution of two varieties of Daphnia carinata in south India ponds. Limnology and Oceanography 23: 452-460.

Olesen, J., 1998. A phylogenetic analysis of the Conchostraca and Cladocera (Crustacea, Branchiopoda, Diplostraca). Zoological Journal of the Linnean Society 122: 491-536.

Post, D. M., T. M. Frost \& J. F. Kitchell, 1995. Morphological responses by Bosmina longirostris and Eubosmina tubicen to changes in copepod predator populations during a whole-lake acidification experiment. Journal of Plankton Research 17: 1621-1632.

Rainbow, P. S. \& P. G. Moore, 1986. Comparative metal analysis m amphipod crustaceans. Hydrobiologia 141: 273289.

Razak, S. A. \& T. Saisho, 1970. Seasonal variations in egg-size, brood size and body length of Bosmina longirostris (Crustacea: Cladocera) from Lake Ikeda, Japan. Malaysian Journal of Science 23: 19-29.

Reissig, M., C. Queimaliños, B. Modenutti \& E. Balseiro, 2015. Prey C: $\mathrm{P}$ ratio and phosphorus recycling by a planktivorous fish: advantages of fish selection towards pelagic cladocerans. Ecology of Freshwater Fish 24: 214-224.

Rice, E., H. G. Dam \& G. Stewart, 2014. Impact of climate change on estuarine zooplankton: surface water warming in Long Island Sound is associated with changes in copepod size and community structure. Estuaries and Coasts 77: $1-11$.

Richter, S., J. Olesen \& W. C. Wheeler, 2007. Phylogeny of Branchiopoda (Crustacea) based on a combined analysis of morphological data and six molecular loci. Cladistics 23: 301-336.

Sakamoto, M. \& T. Hanazato, 2009. Proximate factors controlling the morphological plasticity of Bosmina: linking artificial laboratory treatments and natural conditions. Hydrobiologia 617: 171-179.

Sakamoto, M., K. H. Chang \& T. Hanazato, 2007. Plastic phenotypes of antennule shape in Bosmina longirostris controlled by physical stimuli from predators. Limnology and Oceanography 52: 2072-2078. 
Salo, J., M. Walls, M. Rajasilta, J. Sarvala, M. Räsänen \& V.-P. Salonen, 1994. Fish predation and reduction in body size in a Cladoceran population: palaeoecological evidence. Freshwater Biology 21: 217-221.

Sanford, P. S., 1993. Bosmina longirostris antennule morphology as an indicator of intensity of planktivory by fishes. Bulletin of Marine Science 53: 216-227.

Stenderup, J. T., J. Olesen \& H. Glenner, 2006. Molecular phylogeny of the Branchiopoda (Crustacea)-multiple approaches suggest a 'diplostracan'ancestry of the Notostraca. Molecular Phylogenetics and Evolution 41: 182-194.

Szeroczyńska, K. \& K. Sarmaja-Korjonen, 2007. Atlas of Subfossil Cladocera from central and Northern Europe. Friends of the Lower Vistula Society, Świecie.

Taylor, D. J., T. J. Crease \& W. M. Brown, 1999. Phylogenetic evidence for a single long-lived clade of crustacean cyclic parthenogens and its implications for the evolution of sex. Proceedings of the Royal Society of London Series B: Biological Sciences 266: 791-797.

Taylor, D. J., C. R. Ishikane \& R. A. Haney, 2002. The systematics of Holarctic bosminids and a revision that reconciles molecular and morphological evolution. Limnology and Oceanography 47: 1486-1495.

Texeira de Mello, F., M. Meerhoff, Z. Peckan-Hekim \& E. Jeppesen, 2009. Substantial differences in littoral fish community structure and dynamics in subtropical and temperate lakes. Freshwater Biology 54: 1202-1215.
Urabe, J., 1991. Effect of food concentration on the carbon balance of Bosmina longirostris (Crustacea: Cladocera). Freshwater Biology 26: 57-68.

Vanni, M. J., 1986. Competition in zooplankton communities: suppression of small species by Daphnia pulex. Limnology and Oceanography 31: 1039-1056.

Von Ende, C. N. \& D. O. Dempsey, 1981. Apparent exclusion of the cladoceran Bosmina longirostris by invertebrate predator Chaoborus americanus. American Midland Naturalist 105: 240-248.

Wagner, C. \& R. Adrian, 2009. Cyanobacteria dominance: quantifying the effects of climate change. Limnology and Oceanography 54: 2460-2468.

Wells, L., 1970. Effect of alewife predation on zooplankton population in Lake Michigan. Limnology and Oceanography 15 : 556-565.

Yan, N. D. \& R. Strus, 1980. Crustacean zooplankton communities of acidic, metal-contaminated lakes near Sudbury, Ontario. Canadian Journal of Fisheries and Aquatic Sciences 37: 2282-2293.

Zaret, T. M., 1969. Predation-balanced polymorphism of Ceriodaphnia cornuta Sars. Limnology and Oceanography 17: 171-184.

Zehrer, R. F., C. W. Burns \& S. Flöder, 2015. Sediment resuspension, salinity and temperature affect the plankton community of a shallow coastal lake. Marine and Freshwater Research 66: 317-328. 